In the Department of Surgery Professor Louis Barnett gave up some of his beds to orthopaedics when Renfrew White's appointment with the New Zealand Government ended. The New Zealand School of Physiotherapy had been established for some years, but with Renfrew White's appointment it came under his direction, and its present stature owes much to his influence and enthusiasm. His inherited background in education led him to take more and more interest in medical education. He spent a year in the United States, where he was elected a Fellow of the American College of Surgeons.

In 1925 Sir Gordon Bell was appointed to the Chair of Surgery, succeeding Sir Louis Barnett. He founded a " surgical unit " with the professor and two assistants. James Renfrew White was appointed the assistant in charge of orthopaedic cases.

The Department of Orthopaedics flourished under his care and guidance; in 1936 he was appointed Senior Surgeon and the writer Assistant Surgeon. In the same year all fractures and allied injuries came under his charge and so the Orthopaedic and Traumatic Service of the Otago Medical School and Dunedin Hospital was achieved. During the next decade of rebuilding and extensions to the Hospital, modern orthopaedic wards and a magnificent Physiotherapy School were erected. In the second world war his staff was depleted and he was called upon to carry on the Service with temporary assistants.

When Renfrew White retired from his hospital appointment in 1948 he was a young active " sixty." He continued in private consulting practice for many years, but he now had time to devote himself to his other great interest in life-music. During the years he had composed freely in various forms and had had many compositions performed. Now he took classes in music at the University of Otago and reached the stage when he could sit for the Mus. Bac. degree-a truly outstanding effort at his age.

He then spent a prolonged visit to England, further exploiting his interest in music. He developed a deep interest in the ancient churches of London and compiled a vast manuscript dealing with their history and origins. On his return to Dunedin in 1961 he was immensely busy preparing it for publication, but this was not to be-he died suddenly after a brief illness.

He was a Foundation Fellow of the Royal Australasian College of Surgeons. The British Orthopaedic Association honoured him by electing him an Emeritus Fellow and the New Zealand Orthopaedic Association its Patron.

James Renfrew White was a truly remarkable man, vivacious, erudite and immensely versatile. He more than anyone else was the pioneer and founder of orthopaedic and traumatic surgery in New Zealand. We in New Zealand are much the poorer by his death, and his influence will long be felt in this country.

H. W. F.

\title{
ERIC EVAN PRICE 1905-1962
}

Eric Evan Price died on May 16, 1962, after a long illness, aged only fifty-seven. To his wife and family is extended the sympathy of a host of friends and colleagues. With his death passed the cherished hope of many that he would one day devote some of his tireless energies to writing a textbook. No one in Australia was better equipped to do so. There is no doubt that he could have enriched its pages with innumerable and invaluable items of "know-how" acquired from a long association with the Royal Children's Hospital and the Royal Melbourne Hospital as well as from a very large private practice. It should be easy for one who has known and worked with him for over forty years to write a short appreciation of his life and work. But his was a complex character which, as the years passed in the closest association, from time to time disclosed surprising, even exciting facets, yet never completely revealed itself in its true depth and quality. 
Eric Price was educated in Melbourne, matriculating in 1921 with four first class honours and a Government scholarship to embark upon a career in medicine. Always in the top few of what was surely a "vintage" year, he graduated in 1927 with honours in all three subjects. gaining one of the coveted resident posts at the old Melbourne Hospital. He might have done even better in his final examination in clinical medicine when confronted with a rare case of familial dystrophy, had he not before examining the patient firmly but courteously escorted other similarly afflicted members of the family, thoughtfully "planted" there by the examiners, out of the ward. After his resident year at the Melbourne Hospital he went to the Children's Hospital and began an association which lasted almost without interruption until his death. He took his M.D. before proceeding to England where, as might be expected, he gained his English Fellowship without suffering any of the trials and tribulations that afflicted many of his less gifted colleagues. On his return home the Australasian Fellowship followed as a matter of course. He resumed his work at the Children's Hospital and shortly afterwards joined the newly formed orthopaedic unit at the now Royal Melbourne Hospital as assistant to the late Charles Littlejohn. Thus in the beginning it was perhaps force of circumstances that channelled his career into orthopaedics, and, if indeed this be so, it is difficult to imagine a happier quirk of fate, for his talents were peculiarly suited to orthopaedic surgery. He was possessed of immense patience-in fact

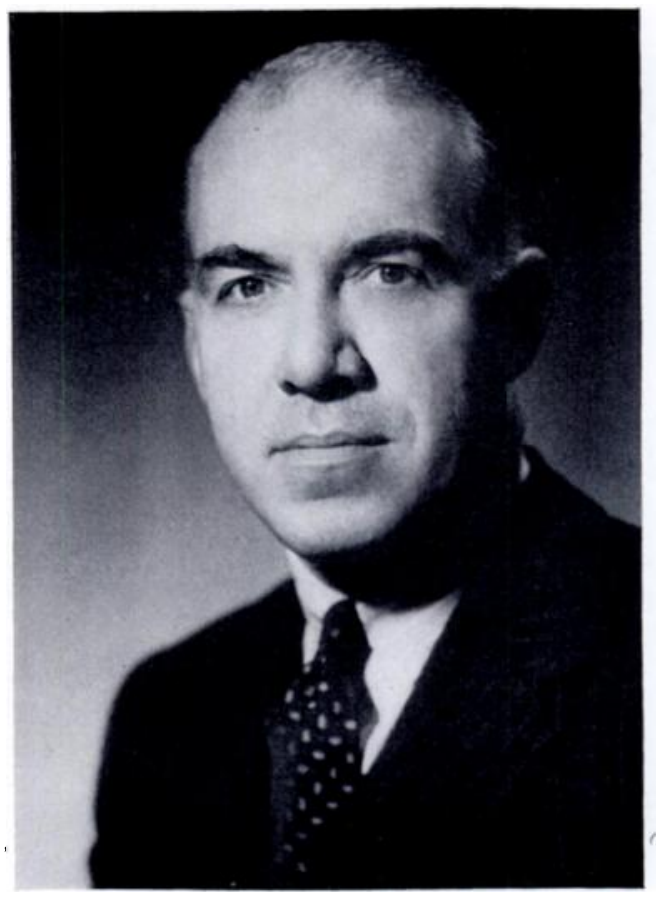
the passage of time meant nothing to him, and he also had the faculty for suffering fools gladly, much more than most. He was a courageous operator with a flair for original techniques made simpler by technical perfection. His management of problems was always based on fundamental principles from which he deemed it amoral to deviate, and for this innumerable patients have reason to be grateful. Nor could we, his immediate colleagues, fail to be influenced by such clinical rectitude, and for this we gladly acknowledge our debt.

But though, after the " maestro" retired in 1947, Eric continued his connection with the orthopaedic unit at the Royal Melbourne Hospital and gave to it the only form of service he knew-loyal, selfless and devoted-the Royal Children's Hospital both at Melbourne and Frankston remained as always his first love, and he lived to become its first Director of Orthopaedic Surgery. Here he was in his element, for his gentle courtesy and kindly, almost benign smile never failed to win the confidence and love of his youthful patients. His opinion on the management of a difficult orthopaedic problem in a child was quite exceptional-indeed in the view of many unsurpassed - and in this regard he was helped by a phenomenal memory for case details. Indeed, he had a unique brain-receptive, retentive and clear thinking. He was perhaps at his best when delivering himself of a considered opinion, which would follow painstaking inquisition and examination. If he had a fault it was that his views were occasionally cloaked in metaphor and in deliciously humorous obliquities of expression, the intent of which, while crystal clear to him, demanded a similar agility of mind in his audience if they were to grasp the full measure of his meaning. He was, however, careful not to cast his pearls promiscuously, and in consequence he was a fine teacher, immensely popular with his students.

VOL. 45 B, NO. 1, FEBRUARY 1963 
Possibly the most lasting memory of Eric Price is of a man of extreme modesty and unswerving integrity. It is perhaps because of these characteristics that he published so littleonly eight papers in all. He was indeed that rare type of medical man who, in spite of having attained great eminence, still thought that unless he had something worth saying it was better to say nothing. That is why these papers, embracing subjects as widely diverse as fractures, giant-cell tumours and painful feet, are so well worth while and rewarding to the reader. His paper on the management of the flail lower limb after poliomyelitis is a little masterpiece in which students of all ages may find basic principles intelligently implemented. Perhaps the most important, written in conjunction with the late Wilfred Forster in 1939, was a report on the investigation of twenty-three cases of poliomyelitis treated by the "Kenny system." Its conclusions were prophetic, and if it did nothing else it was invaluable in exposing for all time many of the inconsistencies and taboos of orthodoxy as having nothing more than tradition to justify them.

For a man who was both dedicated to his work and academically minded Eric was a shrewd observer of the passing show. Young men constantly sought his advice, which was always freely and generously given, while his views on current medical events were eagerly sought by his friends and colleagues. Once he espoused a cause he pursued it relentlessly, particularly if he considered that matters of principle were at stake. He was a regular attender at annual meetings of the Australian Orthopaedic Association and made many valued contributions to the scientific sessions. He always regretted that it has not been possible to train young graduates adequately in Australia in the speciality of orthopaedics. He initiated and championed the movement within the Association which has now resulted in a schedule of training in orthopaedics which will be a fait accompli this year, and as such will be a permanent reminder of his foresight and vision-a fact which young men in the immediate future should not readily forget. He had few interests outside his work and his family, but all his life he had been a keen tennis enthusiast and no mean exponent of the game himself. He could never resist the major tournaments at Kooyong and could usually be found in the members' enclosure when an important match was in progress. Football also held his attention, particularly when his eldest son, now a fourth year student at the Royal Melbourne Hospital, developed into a player of exceptional ability.

Eric Price was a devout Christian devoted both to his family and his Church, and the very large assembly that gathered to say a final farewell was a just and moving tribute to a lovable personality. Apart from his immediate family, those of us who worked with him will perhaps miss him most. There seems now to be a great emptiness in our lives, for somehow it just doesn't seem possible that the lively discussions and always friendly arguments are no more, and that we will never again be privileged to hear those gems of wisdom and whimsy which, during his lifetime, were legend.

B. T. K.-C. 